\title{
Peran Kepemimpinan Kepala Sekolah Dalam Mendukung Budaya dan Mutu SMPK Angelus Custos II Surabaya
}

\author{
Yuliana Pebristofora Marni Mala ${ }^{1}$, Yatim Riyanto ${ }^{2}$,Bambang Sigit Widodo ${ }^{3}$ \\ ${ }^{123}$ Surabaya State University \\ Email: yuliana.19015@mhs.unesa.ac.id
}

\begin{abstract}
The role of the headmaster's leadership in supporting the culture and quality of the school is very influential for the quality of the school. This leadership is oriented to how the role of the headmaster's leadership in supporting the interactive learning process, conducive schoolenvironment, cultured and quality community. The purpose of the research is: (1) describe how the role of the headmaster's leadership in supporting the culture of SMPK Angelus Custos II Surabaya (2) describes how the role of the headmaster's leadership in supporting the quality of SMPK Angelus Custos II Surabaya. This research uses Qualitative research method. Data collection using research instruments with participant observation methods, in-depth interviews, documentation and literature reviews. The results of this study are: (1) the role of the principal leadership at SMPK Angelus Custos II Surabaya in supporting the culture and quality of education is considered as an important element and optimal enough in determining the direction of school success. (2) The impact of the principal's support in improving the culture and quality of education at SMPK Angelus Custos II Surabaya is quite maximal. It can be concluded that the role of the headmaster's leadership in supporting the culture and quality of the school is very influential in improving the quality of the school.
\end{abstract}

Keywords: Leadership Role, Headmaster, School Culture, School Quality.

Abstrak. Peran kepemimpinan kepala sekolah dalam mendukung budaya dan mutu sekolah sangat berpengaruh untuk kualitas sekolah. Kepemimpinan ini berorientasi pada bagaimana peran kepemimpinan kepala sekolah dalam mendukung proses pembelajaran yang interaktif, lingkungan sekolah yang kondusif, masyarakat yang berbudaya dan bermutu. kebijakan kepemimpinan menjadi tolak ukur sekolah dalam meningkatkan kualitas budaya dan mutu sekolah. Tujuan penelitian adalah: (1) mendeskripsikan bagaimana peran kepemimpinan kepala sekolah dalam mendukung budaya SMPK Angelus Custos II Surabaya (2) mendeskripsikan bagaimana peran kepemimpinan kepala sekolah dalam mendukung mutu SMPK Angelus Custos II Surabaya. Penelitian ini menggunakan metode penelitian Kualitatif. Pengumpulan data menggunakan instrumen penelitian dengan metode observasi participant, wawancara mendalam, dokumentasi dan tinjauan literatur. Hasil penelitian ini adalah: (1) peran kepemimpinan kepala sekolah di SMPK Angelus Custos II Surabaya dalam mendukung budaya dan mutu Pendidikan dinilai sebagai elemen penting dan cukup optimal dalam menentukan arahan keberhasilan sekolah. (2) dampak dukungan kepala sekolah dalam peningkatan budaya dan mutu Pendidikan di SMPK Angelus Custos II Surabaya sudah cukup maksimal. Dapat disimpulkan bahwa peran kepemimpinan kepala sekolah dalam mendukung budaya dan mutu sekolah sangat berpengaruh dalam meningkatkan kualitas sekolah.

Kata Kunci: Peran Kepemimpinan, Kepala Sekolah, budaya sekolah, Mutu sekolah.

\section{PENDAHULUAN}

Salah satu komponen penting dalam berkembangnya suatu negara adalah pendidikan. Pendidikan menjadi investasi jangka panjang yang memiliki peran bagi pribadi bangsa dan proses pembentukanya, yang tidak terlepas dari jiwa nasionalis seorang masyarakat negara dimana memegang teguh prinsip berbudaya, berbangsa dan bernegara. Negara maju tentunya memiliki masyarkat yang maju, yang memiliki pola pikir sebagai pembangun dan penggerak melalui system Pendidikan nasional. Pendidikan di Indonesia dapat meningkat dengan mengembangkan mekanisme Pendidikan yang 
dimaksudkan dengan moral religious serta professional, baik dari sisi intelektual maupun pembawaan diri dalam berpendidikan karakternya.

Oleh karena itu kepala sekolah SMPK Angelus Custos II Surabaya menjadikan penguatan pendidikan karakter sebagai parameter dalam mempertimbangkan bahwa agar tercapainya tujuan mewujudkan bangsa yang berbudaya melalui nilai-nilai religious, kedisplinan dalam waktu, berprilaku jujur, semangat dalam bekerja, pantang menyerah, komunikatif, budaya membaca yang baik, jiwa nasionalis mencintai tanah air, gotong royong, peduli sosail dan bertanggung jawab.

Dalam menjadikan Pendidikan nasional yang unggul berkualitas hingga mampu bersaing secara global lembaga pendidikan memiliki andil yang sangat besar, Pendidikan menjadi dasar berkembangnya suatu negara melihat dimana negara-negara lain berkembang karena fokusnya dalam Pendidikan sangat tinggi sehingga pusat perhatian pada Pendidikan ini meningkatkan lembaga Pendidikan itu sendiri dan yang pasti jika Lembaga pendidikanya maju maka Pendidikan dalam negara juga akan maju. Ketika membicarakan Lembaga tentunya tidak terlepas dari kepemimpinan seorang pemimpin dalam Lembaga.

Peraturan ini diimpelementasikan dalam SMPK Angelus Custos II Surabaya dengan menyeimbangkan tujuan Pendidikan Indonesia dan meningkatkan martabat Indonesia sebagai bangsa yang berbudaya dan bernegara dengan menjunjung tinggi 5 poin penting Religius, Integritas, Gotong royong, Mandiri, Nasionalis. Fokusnya kepala sekolah dalam menerapkan nilai-nilai tersebut tentunya membawa angin segar bagi terbentuknya masa depan kehidupan berbangsa dan bernegara yang memiliki nilainilai luhur dan berkarakter.

Permasalahan-permasalahan di atas menjadi perhatian kepala sekolah SMPK Angelus Custos II Surabaya, sehingga mulai dari hal yang terkecil dalam lingkungan sekolah, seperti bagaimana peranya sendiri sebagai pemimpin sekolah dalam mendukung budaya sekolah yang menjadi komponen lainya dalam mengembangkan mutu sekolah.
Kepala sekolah SMPK AC II memiliki peran utama dalam menjalankan kepemimpinan, profesionalnya menjadi kepala sekolah merupakan salah satu kualitas dalam membimbing dan memimpin, bagaimana kemampuanya mendukung, membangkitkan motivasi tenaga pendidik hingga bagaimana dapat bertanggung jawab pada kreatifitas guru dan menjadikanya prestasi tenaga pendidik, Rendahnya motivasi berprestasi tenaga pendidik terkait hubungan dengan hasil peserta didik nantinya. dalam hal ini adalah guru yang menjadi stimulus serta memiliki kesempatan untuk mengamati lebih dekat peserta didik. Formulasi awal kepemimpinan instruksional diasumsikan sebagai tanggung jawab kepala sekolah.

Terlepas dari model kepemimpinan kepala sekolah SMPK AC II Surabaya sebagai seorang pemimpin, peran penting lain dari kepala sekolah juga dalam mendukung serta melestarikan budaya dan mutu sekolah, dalam membentuk karakter lembaga sebagai identitas yang unik dari Lembaga lainya, memiliki posisi sebagai seorang kepala sekolah tentunya sudah menjadi tugas untuk menjaga dan melestarikan budaya mutu yang sudah ada. Begitu kompleksnya tugas dan tanggungjawab kepala sekolah SMPK AC II Surabaya dalam menjalankan manajemen sekolah yang dipimpinya sehingga untuk menjadi kepala sekolah harus professional dan memiliki skill yang memadai.

Budaya yang dikembangkan di sekolah akan menumbuhkan disiplin dan etos belajar peserta didik yang baik. Ki Hajar Dewantara mengatakan bahwa manusia membudaya itu maksudnya untuk kehidupanya sendiri dimana menyelamatkan dan membahagiakan dirinya dalam proses perjuanganya. Di lain pihak masyarakat juga mempengaruhi kebudayaan begitupun sebaliknya kebudayaan mempengaruhi masyarakat. Berdasarkan ungkapan Mayer dan Rowen (Jamaluddin, 2008: 24) budaya sekolah menjadi salah satu dorongan yang kuat (power) pembentukan sekolah efektif jika budaya sekolahnya kuat dan akan memberikan makna terhadap kegiatan yang dilaksanakan dalam sekolah guna meningkatkan kualitas sekolah itu sendiri, sehingga yang di unggulkan oleh kepala Sekolah SMPK AC II 
adalah bagaimana masyarakat sekolah itu sendiri dapat mengimplementasikan nilai-nilai budaya sekolah yang hidup, dalam artian semua proses pencapaianya dimulai secara internal. Kepala Sekolah SMPK AC II menerapkan peranan yang penting dalam menjalankan kepemimpinanya dimana dalam menjadi panutan, kualitas kepala sekolah menentukan pula kualitas guru serta karyawan lainya dalam lingkungan sekolah, terutama di era kompetetif dan dunia yang semakin global, dibutuhkan guru yang memiliki motivasi berprestasi tinggi untuk meningkatkan budaya dan mutu sekolah.

Ridho (2019) menerangkan beberapa ciri-ciri utama sekolah efektif, dari berbagai hasil penelitian yang didapatkan: (a) Kepemimpinan instruksional yang baik; (b) Usaha dalam meningkatkan prestasi peserta didik; (c) Situasi dan kondisi lingkungan yang nyaman; (d) Ketrampilan dasar yang unggul; (e) Bimbingan dan arahan dalam meningkatkan prestasi peserta didik; (f) Rumusan tujuan sekolah yang pasti, oleh karena itu Kepala sekolah SMPK AC II Lebih spesifik dalam menerapkan kepemimpinanya dimana sebagai suatu organisasi dengan system yang terstuktur, ada tiga poin utama yang memiliki keterkaitan dengan sekolah efektif yang diintegrasikan kepala sekolah yaitu proses kegiatan belajar mengajar, pemimpin dalam kepemimpinanya dan manjemen sekolah serta budaya dan mutu sekolah yang baik.

Bertanggungjawabnya kepala sekolah SMPK AC II berpengaruh dalam menentukan segala aktivitas dan kebijakan yang harus dijalankan dan dipatuhi oleh masyarakat sekolah. Sehingga faktor yang tak kalah pentingnya dalam meningkatkan keefektifan sekolah adalah faktor kepemimpinan kepala sekolah yang baik. Terwujudnya budaya dan mutu sekolah yang baik tidak terlepas dari bagaimana peran kepemimpinan seorang kepala.

Beberapa hasil penelitian mengungkapkan bahwa ada beberapa hubungan antara kepemimpinan seorang pemimpin sekolah dengan budaya dan mutu sekolah. Hasil penelitian Kosim (2017: 34) menunjukan ada keterkaitan yang signifikan antara bagaimana kepemimpinan yang diajalnkan seorang kepala sekolah dengan mutu pembelajaran yang secara tidak langsung berhubungan dengan peningkatan mutu sekolah. Hasil penelitian Fadhli (2013: 62) menunjukan adanya keterkaitan yang meningkat dari kepemimpinan seorang kepala sekolah dengan budaya sekolah dalam meningkatkan keefektifan sekolah Kota Medan.

SMP Angelus Custos II adalah salah satu Lembaga Pendidikan katolik yang berada di Surabaya. Tepatnya di jalan Kebraon Widya No.15-17, Kebraon, Kec. Karang Pilang. SMP Angelus Custos dipimpin oleh kepala sekolah seorang Frater yaitu Frater Bere. Dalam masa kepemimpinanya menjadi kepala sekolah SMP Angelus Custos, frater bere menerapkan beberapa program kerja tahunan yang menjadi budaya sekolah dan keunggulan SMP Angelus Custos ini.

Dalam upaya mendukung budaya dan mutu sekolah, kepala sekolah SMP Angelus Custos II Surabaya, mengimpelentasikan model pembelajaran yang berbeda dari sekolah lainya salah satunya yaitu proses pembelajaran berbasis LAB, serta menerapkan beberapa peraturan yang menjadikan SMP Angelus Custos II Surabaya ini memiliki keunggulan yang unik dari Lembaga Pendidikan yang lainya.

Dapat disimpulkan bahwa peran kepemimpinan kepala sekolah dalam mendukung budaya dan mutu sekolah memiliki pengaruh untuk kualitas budaya dan mutu sekolah. Disini penulis melakukan penelitian secara Kualitatif di lapangan (sekolah) bagaimana manajemen kepemimpinan seorang pemimpin sekolah dalam meningkatkan budaya dan mutu sekolah. Penelitian ini di lakukan di SMP Angelus Custos II Surabaya.

\section{KAJIAN TEORITIS}

\section{Defenisi Kepemimpinan Kepala Sekolah}

Leadership dalam kepemimpinan merupakan Langkah yang diambil seseorang dalam memimpin dengan proses mempengaruhi bawahan atau orang lain. Menurut Nawawi (Damero: 2017) arti kepemimpinan adalah sebagai kelebihan atau kemampuan menstimulus orang-orang agar agar bersama-sama bergerak dalam menjalankan kegiatan untuk mencapai tujuan bersama. Pencapaian unggul kerja dalam organisasi sekolah bergantung pada kecakapan seorang pemimpin dan dan motivasi yang selalu 
diberikan, agar guru dan karyawan dapat menjalankan tanggung jawab dalam tugasnya masing-masing.

Seseorang dapat meningkatkan prestasi kerjanya dengan keseriusan dalam memahami dan menjalankan tugasnya didukung dengan kecakapan dan pengalaman yang diperolehnya serta professional dalam bidangnya. Menurut Imam (Thomas: 2013) merumskan 3 poin penting dalam meningkatkan prestasi kerja, yaitu: (1) meningkatkan hasil kerja yang lebih baik, (2) konsisten terhadap waktu, (3) membuat ukuran tersendiri. Sehingga konsep lain mengatakan bahwa dalam prestasi kerja adalah kesanggupan guru sebagai pegawai negeri yang disiplin pada pekerjaan yang menjadi tugasnya. Hersey dan Blanchard (1993) mengatakan pemimpin dalam suatu organisasi mendapatkan dukungan, masukan, suport dan tenaga dari bawahanya, harus meningkatkan hubungan kerjasama dengan bawahan tersebut dalam mencapai tujuan organisasi.

Secara umum kepemimpinan berakar pada ajaran etika dan moral, memimpin, memptivasi orang-orang untuk mencapai tujuan dan kesuksesan. Karakter dari kepemimpinan adalah mengajak serta memberikan suport pengikutnya untuk bertindak berdasarkan tujuan tertantu yang yang menjadi stimulus dalam pergerakan mereka. Para peneliti memiliki banyak kesimpulan mengenai kepemimpinan menurut pandangan mereka dimana ditinjau dari beberapa penelitian terdahulu adalah sebuah seni mengarahkan antusiasme dan kepercayaan diri agar bawahan dapat melaksanakan tugas sebagai kemampuan untuk membimbing pengikut menuju tujuan bersama.

Bass (1987) menyimpulkan: there are almost as many defenitions of leadership as there are person have attempted to define the concept. Thoha (Adnan: 2016) misalnya mendefenisikan kepemimpinan kegiatan yang mempengaruhi orang-orang dan mengarahkanya pada tujuan yang dibuat.

Seorang kepala sekolah adalah panutan guru-guru dan peserta didik serta menjadi pencetus budaya yang diamalkan di sekolah, tindakan-tindakan yang diambilnya mencerminkan gaya kepemimpinanya, Pengetahuan baru, peningkatan kinerja dan efisiensi. Pemimpin menjadi penanggung jawab dengan masa depan yang dibentuknya. Kepemimpinan seseorang harus dapat menjelaskan visi yang jelas, dapat diterapkan, dan diimplementasikan. Visi dan misi yang di rancang harus menyadari kebenaran sebuah rencana aksi untuk perbaikan sekolah. Pemimpin juga berfokus dengan peserta didik dalam memimpin kegiatan belajar mengajar, menyusun strategi dengan standar yang baik agar dapat meningkatkan budaya dan mutu sekolah Day \& Armstrong (2016: 249). Langkah pengawasan seperti pemantauan dan evaluasi praktek mengajar dengan kualitas yang baik juga terus dijalankan untuk menjamin terjaganya pembelajaran. Kepemimpinan yang diimplementasikan menjadi sebuah proses menstimulus berdasarkan kepercayaan dari orang lain dan kejelasan nilai moral yang memimpin mereka menuju visi sekolah Bush (2007), namun wajib disadari bahwa kepemipinan pada pendidikan sangat kompleks dan beragam.

Sebagaimana dijelaskan Hallinger \& Heck (1998) dimana seorang kepala sekolah harus aktif menjalankan kegiatan dalam mencapai tujuan sekolah. Kualitas kepemimpinan seorang kepala sekolah memiliki implikasi yang sangat besar bagi prestasi belajar peserta didik.

Syafarudin (2002: 49), Menjelaskan kepemimpinan seorang pemimpin sebagai kemampuan dalam mempengaruhi atau menstimulus seseorang atau sekelompok orang agar secara sukarela bekerja dalam mencapai tujuan atau sasaran yang ingin dicapai. Seorang manajer dikatakan seorang pemimpin apabila dapat mempengaruhi orang lain untuk mencapai tujuan tertentu, tetapi seorang pemimpin belum tentu menjadi seorang manajer.

Mulyasa (2005: 107), Menyimpulkan bahwa kemampuan seorang dalam memimpin untuk mengggerakkan, memotivasi, ajakan, mengarahkan, menasehati, membimbing, mengatur, melarang, dan memberikan sangsi sebagai hukuman, serta membina agar maksud manusia sebagai manajemen media akan bekerja dalam rangka mencapai tujuan administrasi efektif dan efisien. Kutipan diatas memberikan penjelasan dimana sekolah memiliki penekanan 
pada pentingnya posisi kepemimpinan seorang kepala sekolah dalam mendukung budaya dan mutu sekolah.

Peran yang dijalankan oleh seorang pemimpin dia artikan sebagai kegiatan yang diharapkan untuk dilakukan oleh seseorang sesuai kedudukanya sebagai seorang pemimpin dimana pekerjaan yang dilakukan sesuai dengan peran yang beriringan dengan pekerjaan tersebut (Rivai, 2007)

Sergiovanni (Bharudin: 2017) menjelaskan ada 6 peran kepemimpinan seorang Kepala Sekolah, yaitu: pemimpin formal, kepemimpinan administratif, kepemimpinan organisasi, kepemimpinan supervisi dan kepemimpinan tim.

Lebih spesifik, kepemimpinan kepemimpinan kepala sekolah dapat mengungkapkan tentang mengeksplorasi lima peran kunci yang digunakan oleh pemimpin yang efektif (Rahmat, 2017). Dimana posisi tersebut adalah a) katalisator yang tajam, b) motivator visioner; c) konektor terukur; d) pelaksana yang ulet; dan e) arsitek yang bijaksana. Dimana dijelaskan pada poin-poin berikut.

- Peran kepemimpinan kepala sekolah sebagai katalisator yang semangat. Peran sangat peka terhadap apa yang bisa dilakukan selanjutnya, fokus dalam peran ini memberikan arahan yang jelas dalam menindaklanjuti Langkah yang yang akan di ambil. Peran ini sangat cocok dalam melakukan prengkrutan organisasi dimana setiap aktifitas dapat didefenisikan dengan baik.

- Peran kepemimpinan kepala sekolah sebagai motivator yang visioner dimana pada peran ini kompeten dalam memanfaatkan sumber daya yang ada dalam organisasi baik SDM maupun SDA lainya. Inspirasi dan semangat yang diberikan sebagai motivasi oleh kepala sekolah mendukung dan mempertahankan mutu sekolah dimasa yang akan dating karena pilar pembentuknya dirangsang terlebih dahulu.

- Peran kepemimpinan kepala sekolah sebagai penghubung yang terkendali dimana pimpinan sekolah menekankan pada keterhubungan seluruh masyarakat sekolah sehingga dapat melakukan komunikasi secara optimal, secara tidak langsung peran kepala sekolah ini membangun kemandirian masyarakat sekolah dimana menjalankan tugasnya tanpa menunggu arahan dari atasan dengan efisien.

- Peran kepemimpinan kepala sekolah sebagai pelaksana yang teguh. Pemimpin ini konsisten dalam menjalankan pekerjaan yang berpegang pada perencanaan akan memberikan kesuksesan bagi Lembaga sekolah karena prinsipnya adalah ketepatan baik dari segi waktu, kualitas sampai pada efisiensi anggaran pada suatu pekerjaan.

- Peran kepemimpinan kepala sekolah sebagai ahli yang bijaksana. Kepemimpinan dalam peran ini mengunggulkan kreatifitas dalam berinovasi dimana konsep-konsep baru yang diciptakan oleh kepala sekolah mengarah pada strategi sekolah yang efektif. Setelah membuat konsep-konsep tersebut, kepala sekolah akan merancang dan mengimpelemntasikan keterlaksanaanya dalam program sekolah.

Mulyasa (Ismayani: 20) menyamapaikan bahwa seorang kepala sekolah harus melakukan perannya sebagai pimpinan yang baik, dimana merangkap menjadi: educator, manager, administrator, dan supervisor, innovator dan motivator dalam waktu bersamaan.

1) Sebagai Educator, kepala sekolah harus memiliki strategi yang tepat untuk meningkatkan keprofesionalisme stakeholder dalam sekolahnya. Menurut Mulyasa (Rusdiana: 2018) sebagai educator kepala sekolah mampu menciptakan dan membangkitkan iklim sekolah yang kondusif, mampu menyesuaikan situasi dan kondisi yang ada serta menjadi penanggung jawab pada prestasi bawahan baik guru maupun peserta didik agar secara beriringan pemimpin dapat mengendalikan dan mengarahkan pada tujuan yang ingin dicapai bersama mulai dari memberikan nasehat kepada warga sekolah sampai melaksanakan supervisi proses pembelajaran guru.

2) Sebagai Manager, kepala sekolah mampu menyusun program, kemampuan menyusun organisasi/personalia, kemampuan menggerakkan staf guru dan karyawan, kemampuan mengoptimalkan sumber 
daya sekolah. Dalam upaya mencapai tujuan kependidikan di sekolah peranan tenaga kependidikan sangat menentukan sehingga kepala sekolah dapat mempengaruhi dan menggerakan semua sumber daya Pendidikan dapat memacu pencapaian kualitas Pendidikan, dengan memperdayakan tenaga pendidik pada strategi kerja yang kooperatif.

3) Administrator, sebagai seorang pemimpin kepala sekolah tentunya perlu memahami dokumentasi sekolah secara keseluruhan. Menurut Warsito (2005; 5) terdapat dua tugas utama kepala sekolah sebagai administrator yaitu sebagai pengontrol struktur organisasi, dimana mengontrol cara membuat laporan, siapa yang berinterkasi dan dengan siapa pekerjaan itu dilakukan. Kedua, administrasi substansif yang dilaksanakan meliputi administrasi kurikulum, peserta didik, personalia, keuangan, sarana dan prasarana, serta administrasi umum.

4) Supervisor, sekolah yang bermutu dan memiliki budaya sekolah selalu memiliki kepala sekolah yang baik dan professional dimana peranya sebagai pemimpin Lembaga wajib memberikan bimbingan dan membina para guru serta stajeholder lainya dalam lembaga Pendidikan (sekolah). Namun sebagai supervisor kepala sekolah harus memahami arahan yang akan dilakukanya secara teliti sebelum memberikan arahan bawahanya yang dapat diperlukan bagi kemajuan sekolahnya.

5) Leader, Wahjosumijo (Ariyani: 2017) berpendapat bahwa sebagai leader kepala sekolah memiliki karakter khusus dalam membawa diri berdasarkan pengalaman, pengetahuan yang professional serta dalam pengawasan.

6) Sebagai Innovator Menurut Mulyasa (Putra: 2020) kepala sekolah sebagai seorang inovator mampu dalam menciptakan modelmodel yang inovatif serta menjadlin hubunngan yang harmonis dengan lingkungan, mengembangkan ide-ide yang ada dan mengimplementasikan ide-ide yang baru serta mengintergrasikan dalam kegiatan agar menjadi teladan masyarakat sekolah.
Menurut Komariah (Putra: 2020) inovator adalah pencetus, penggerak pada pembaharuan inovasi-inovasi yang ada, dalam hal ini kepala sekolah melakukan pembaharuan pada system Pendidikan agar berkualitas agar mampu beradaptasi dengan perkembangan zaman dalam mendukung budaya dan mutu sekolah.

7) Motivator, kepala sekolah sebagai motivator memiliki peran penting sebagai stimulus stakeholder dengan ketepatan strategi dalam memberikan motivasi pada masyarakat sekolah yang lainya. Dengan kuatnya motivasi yang dibangkitkan pada diri seseorang maka minat dan tekad seseorang dalam melakukan hal yang diinginkan akan kuat. Bagi Lembaga itu dapat membantu mempertahankan mutu sekolah yang ada dan menjadi lebih baik diiringi dengan keefektifan budaya sekolah.

Dalam Lembaga Pendidikan, kepala sekolah sebagai pemimpin tingkat satuan Pendidikan yang memiliki rentang kendali sebagai teladan dalam menuntun anggotanya ke arah yang lebih baik. Gaya kepemimpinan seorang kepala sekolah tentu harus mampu mengarahkan, membimbing, memotivasi serta mempercayai guru-guru serta karyawan dalam menjalankan tugas-tugas guna mencapai tujuan Bersama. Menurut Hasibuan (2012: 167) menyatakan bahwa: "cara untuk mempengaruhi bawahan salah satunya adalah gaya kepemimpinan seorang pemimpin, agar secara produktif mau bekerja sama dalam mencapai tujuan organisasi.

Bush (2008:4) menyatakan bahwa pemimpin adalah orang yang memegang kendali dalam memotivasi, dan mengatur bawahanya guna mencapai tujuan-tujuan yang dirancang. Sebagai seorang yang memimpin, pemimpin mengorganisasikan segala kegiatan yang berjalan di sekolah. Smith \& Piele Syaeba (2018) mengatakan kepemimpinan sekolah yaitu "The activity of mobilizing and empowering others to serve the academic and related needs of students with utmost skill and integrity." Kepemimpinan dalam sebuah Lembaga Pendidikan menjadi center Lembaga itu dalam pelayanan akademik terbaik yang tepat akan kebutuhan peserta didik, termasuk intergritas keterampilan peserta didik. 
Kepala sekolah memiliki peran center dalam menjalankan kepemimpinan. profesionalnya seorang kepala sekolah menjadi salah satu kualitas memimpin, bagaimana seorang kepala sekolah mampu membangkitkan motivasi tenaga pendidik hingga bagaimana kepala sekolah bertanggung jawab pada kreatifitas guru dan menjadikanya prestasi tenaga pendidik, motivasi berprestasi tenaga pendidik terkait hubungan dengan hasil peserta didik nantinya, dalam hal ini adalah guru yang menjadi stimulus serta memiliki kesempatan untuk mengamati lebih dekat peserta didik tentu akan mempengaruhi prestasi peserta didiknya dalam mendukung budaya dan mutu sekolah.

Sejauh ini banyak gaya kemimpinan yang digunakan oleh kepala sekolah dalam memimpin Lembaga sekolahnya, tetapi belum ada satupun gaya kemimpinan yang efektif untuk diterapkan secara khusus. Ada beberapa gaya kepemimpinan pada pada seorang pemimpin. Antara lain:

- Gaya kepemimpinan Partisipatif

Kepemimpinan partisipatif merupakan gaya kepemimpinan dimana seluruh individu mempunyai kekuasaan setara dalam proses pengambilan keputusan bersama, terlepas menurut kedudukanya. Pemimpin menstimulus dengan isu, masalah, atau planning mengenai perusahaan pada seluruh staf. Peran pemimpin disini lebih menjadi moderator atau fasilitator buat memberikan bimbingan dan menjaga diskusi permanen seimbang serta terkendali, Dari situ anggota diskusi saling mengembangkan ilham, masukan, atau pendapat mengenai bagaimana cara terbaik menuntaskan masalah. Pemimpin setelahnya merangkum keterangan serta pemahaman. Suara terbanyak memilih arah tindakan yang akan diambil perusahaan (majority wins). Meski begitu, kadang terdapat beberapa perkara dimana pemimpinlah yg berhak memilih keputusan akhir, menurut pertimbangan langsung dalam menjalankan diskusi tersebut. Tanggung jawab dalam menjalankan keputusan nantinya akan dibagi homogen antara seluruh anggota staf sesuai tugasnya masing-masing.
- Gaya kepemimpinan Visioner

Yang ditunjukan dalam kepemimpinan ini adalah pemimpin mengarahkan bawahanya dengan menjelaskan secara mendalam arti dan tujuan kerja yang dilaksanakan sehingga membangkitkan motivasi bawahan bahwa pentingnya tercapai tujuan yang dibuat sehingga menjadi tekun dan bersungguh-sungguh dalam bekerja.

- Kepemimpinan Instruksional

kepemimpinan instruksional mengamati dan menginstruksikan dalam meningkatkan lingkungan belajar di sekolah. Pemantauan atau supervisi yang dilakukan bertujuan untuk mengevaluasi keefektifan belajar mengajar, memberikan bimbingan, dan dorongan. Hal ini mampu meningkatkan kualitas penyampaian pengajaran guru secara terus menerus dan memastikan pencapaian tujuan pembelajaran sejalan dengan tujuan sekolah, potensi yang dimiliki pemimpin instruksional dapat meningkatkan mutu lembaga dan keefektifan budaya sekolah.

\section{METODE PENELITIAN}

Pendekatan yang digunakan dalam penelitian ini adalan pendekatan kualitatif (Qualitative research). Bogdan dan Taylor (Moleong, 2001: 21) menyatakan bahwa data yang dihasilkan dalam penelitian kualitatıf adalah data deskriptif berupa tulisan dari perilaku sesorang, pengamatan pada kejadian, atau tempat tertentu secara rinci. Hasil penelitian ini mendeskripsikan kepemimpinan kepala sekolah dalam meningkatkan budaya dan mutu sekolah sekolah di SMP Angelus Custos II Surabaya. penelitian ini adalah penelitian yang bersifat deskripsi atau menjelaskan secara rinci mengenai hasil temuan pada penelitian yang dilakukan, menganalisis proses sejauh mana Langkah yang di ambil dalam pelaksanaanya penelitian yang dilakukan, poin utama yang diperhatikan adalah proses pelaksanaanya dan ciri yang terakhir adalah dimana penelitian yang dilakukan menjadi instrument kunci. Data-data penelitian ini berasal bahasa lisan, tulisan, dan perilaku yang dapat diamati dengan wawancara, observasi, dan dokumentasi. 
Tabel 3.1. Informan Penelitian

\begin{tabular}{|c|l|c|}
\hline No & \multicolumn{1}{|c|}{ Jabatan } & Jumlah \\
\hline 1 & Kepala Sekolah & 1 \\
\hline 2 & Wakil kepala sekolah & 1 \\
\hline 3 & $\begin{array}{l}\text { Pendidik dan Tenaga } \\
\text { Pendidik }\end{array}$ & 6 \\
\hline 4 & Karyawan & 2 \\
\hline 5 & Orang Tua Peserta Didik & 2 \\
\hline
\end{tabular}

\section{HASIL DAN PEMBAHASAN}

\section{a. Kepemimpinan Kepala Sekolah}

Kepala sekolah sesuai dengan kedudukanya sebagai pemimpin dalam sekolah, memiliki sifat yang melekat yaitu kemampuan berkomunikasi, berinteraksi, membangun relasi, berpengetahuan luas, yang kemudian mampu mempengaruhi, mendorong, mengarahkan, membimbing masyarakat sekolah lainya yang berimplikasi pada pencapaian tujuan yang dirancang dengan kinerja yang memuaskan.

Dalam upaya meningkatkan budaya dan mutu sekolah, kepala sekolah mempunyai peranan penting sebagaimana dijelaskan dalam pasal 12 ayat 1 pp 28 tahun 1990 bahwa kepala sekolah bertanggung jawab atas penyelenggaraan kegiatan Pendidikan, administrasi sekolah, pembinaan tenaga kependidikan, pendayagunaan serta pemeliharaan sarana dan prasarana.

Secara umum, peran lain kepala sekolah sebagai seorang pemimpin adalah sebagai pendidik. Seperti yang diketahui kepala sekolah sebagai pendidik adalah orang yang mendidik, membimbing mengenai kecerdasan dalam bekerja dan karakter yang dimpelementasikan dalam lingkungan sekolah, sebagai seorang pendidik kepala sekolah menanamkan, memajukan, dan meningkatkan paling tidak empat macam nilai yaitu mental, moral, fisik, dan artistik. Selain itu dalam meningkatkan budaya dan mutu sekolah, kepala sekolah memperhatikan lima dimensi kompetensi yang telah ditetapkan dalam peraturan Menteri Pendidikan nasional yaitu: kepribadian, manajerial, kewirausahaan, supervisi dan sosial.

Dijelaskan oleh Wahjosumidjo (2002: 83) yang mengartikan bahwa kepala sekolah adalah seorang tenaga fungsional guru yang diberi tugas untuk memimpin suatu sekolah dimana diselenggarakan proses belajar mengajar atau tempat dimana terjadi interaksi antara guru yang memberi pelajaran dan murid yang menerima pelajaran. Kepemimpinan seorang kepala sekolah SMPK Angelus Custos II sangat menekankan pada pertanggungjawabanya, karena tanggung jawab kepala sekolah sangat penting dalam menentukan meningkatnya budaya dan mutu sekolah yang terukur dari banyak hal seperti produktivitas dan semangat kerja guru yang bergantung pada sejauh mana kepala sekolah mampu mendorong bawahanya untuk bekerja sesuai dengan kebijakan dan program yang ditekankan agar dapat meningkatkan budaya dan mutu sekolah. Berkenan dengan hal di atas, jika dikaitkan dengan pendapat Wahyosumidjo (2010: 90) peran khusus kepala sekolah tidak terlepas dari ilmu Pendidikan didalam pelaksanaan peranya sebagaimana diungkapkan oleh Harry Mintzberg mengenai tiga peranan pemimpin yaitu; interpesrsonal roles, informational roles dan decisional roles.

Peranan hubungan interpersonal roles, timbul dikarenakan otoritas seseorang yang meliputi; sebagai lambang atau figurehead seperti kepala sekolah yang memiliki kedudukan sebagai seorang pemimpin yang mampu memelihara nama baik sekolah dan meningkatkan keunggulan sekolah. Yang berikutnya adalah leadership mencerminkan panutan yang mampu menggerakan, mengontrol seluruh sumber daya yang ada di sekolah sehingga produktifitas kerja yang tinggi dari bawahan mampu mencapai tujuan, dan orotitas formal seorang kepala sekolah yang terakhir adalah sebagai penghubung atau liaison dimana fungsi kepala sekolah berperan menjadi penghubung antara kepentingan internal sekolah dengan eksternal. Sebagai lambang kepala sekolah SMPK Agelus Custos II memiliki integritas diri yang tinggi. Dengan diterapkanya Pendidikan karakter di sekolah, kepala sekolah tentu saja menjadi cermin untuk bawahan yang lainya untuk bersikap santun kepada satu sama lainya, sehingga banyak pendapat yang mengatakan bahwa dalam lingkungan sekolah tidak memandang kasta atau kedudukan, semua 
memiliki tempat dan tugasnya untuk mencapai tujuan yang sama yaitu visi dan misi sekolah.

Peranan informasional (informational roles) kepala sekolah berperan sebagai monitor; dimana kepala sekolah melakukan pengamatan terhadap lingkungan yang memungkinkan adanya informasi-informasi yang berpengaruh terhadap peningkatan budaya dan mutu sekolah. Kemudian peranan informasional sebagai disseminator dimana kepala sekolah bertanggungjawab menyampaikan Kembali informasi-informasi yang didapat kepada bawahan. Dan peran informasional sebagai spokesman, kepala sekolah menyebarluaskan informasi kepada khalayak umum yang dianggap perlu dan semuanya bertujuan agar dapat meningkatkan budaya dan mutu sekolah. Disini kepala sekolah SMPK Angelus Custos II Surabaya sesuai dengan pendapat bahwa kepala sekolah salah satu tipe kepemimpinan yang instruksional, setelah mendapatkan informasiinformasi akan difloorkan dan diisntruksikan kepada guru-guru dan karyawan lainya.

Peranan yang terakhir sebagai decisional roles atau peranan pengambil keputusan, yang memiliki 4 macam peran kepala sekolah. Yaitu; (a) enterpreuner dimana dalam peran ini kepala sekolah melalui berbagai macam pemikiran agar dapat berinovasi memperbaiki penampilan sekolah melalui program-program yang baru, serta melakukan survei agar lebih memahami perkembangan lingkungan sekolah. distrubancehander atau sebagai orang yang memperhatikan gangguan yang timbul seperti contoh saat pandemic sekarang ini, kepala sekolah dengan cekatan mengambil langkah agar system pembelajaran tidak mengalami gangguan karena situasi dan kondisi pandemic saat ini. (c) A negotiator roles, dimana dalam fungsi ini kepala sekolah harus mampu berdiskusi dengan pihak luar agar dapat menjalin kerja sama dan saling memenuhi kebutuhan baik dunia Pendidikan maupun dunia usaha. (d) a resource allocater atau sebagai penyedia segala sumber, disini kepala sekolah bertanggung jawab untuk menentukan siapa yang berhak memperoleh sumber yang disediakan seperti SDM, dana, perlatan dan berbagai kekayaan sekolah lainya. Dalam kasus ini kepala sekolah SMPK Angelus Custos II akan melihat dari segi kinerja guru misalnya dalam penyampainya kepala sekolah mengatakan bahwa terkadang ada guru yang bekerja diluar jam dan ranah kerjanya agar beberapa masalah yang timbul dapat teratasi maka kemudian akan diberikan uang tambahan sebagai reward untuk kerja kerasnya.

a. Gaya Kepemimpinan Kepala sekolah

Kepala sekolah SMPK Angelus Custos II Surabaya mengiplementasikan beberapa gaya kepemimpinan yang memungkinkan dapat diterapkan disekolah dan dapat membangun Kerjasama yang baik dengan bawahan. Dalam menerapkan gaya kepemimpinanya, kepala sekolah menyesuaikan dengan situasi dan kondisi sehingga jalan yang diambil dalam mengelola sekolah tepat pada sasaran.

Misalnya dalam menginstruksi, kepala sekolah akan menginstruksi bawahanya jika kepala sekolah merasa bahwa program kerja yang ditanggungkan pada seseorang atau pada bidang tertentu perlu untuk di arahkan dan menjadi pengingat, dan akan menjadi pemimpin yang partisipatif jika kepala sekolah merasa bahwa bawahanya atau program tersebut membutuhkan motivasi dengan adanya keterlibatan kepala sekolah dalam pelaksanaanya, maka kepala sekolah akan melibatkan diri mengambil bagian dalam pelaksanaan kegiatan tersebut, tetapi jika kegiatan tersebut atau bawahanya dirasa cukup mampu untuk menyelesaikan dengan baik maka kepala sekolah akan memantau tanpa perlu melibatkan dirinya. Dalam hal menjadi pemimpin yang visioner kepala sekolah cukup memiliki rasa tanggungjawab yang tinggi terhadap visi yang ada Setiap keputusan, Tindakan yang diambil semuanya tetap akan kembali ketujuan semula. Sedangkan menjadi pemimpin yang delegative, kepala sekolah SMPK Angelus Custos II Surabaya sering kali menumbuhkan motivasi bawahan dengan memberika kepercayaan kepada bawahanya untuk menangani masalah ataupun memberikan wewenang kepada bawahan yang sekiranya diyakini dapat dipercaya dan memiliki kematangan persiapan dalam pekerjaanya dalam mengambil keputusan dan arahan pekerjaanya. Dan yang terakhir adalah kepemimpinan yang juga diimplementasikan 
oleh kepala sekolah SMPK Angelus Custos II Surabaya yaitu karismatis dimana kepala sekolah dengan caranya selalu membangun energi positif dengan komunikasi dan komitmen yang kuat diantara guru-guru dan karyawan yang lain.

b. Peran Kepemimpinan Kepala sekolah

Peran kepala sekolah SMPK Angelus

Custos II Surabaya dalam mendukung budaya dan mutu sekolah sebagai pemimpin adalah menciptakan lingkungan sekolah yang berkarakter, berbudaya dan bermutu. Dalam melaksanakan peran tersebut, kepala sekolah SMPK Angelus Custos II Surabaya memiliki banyak pekerjaan ganda lainya seperti sebagaimana peranya sebagai educator (pendidik) kepala sekolah bertanggungjawab dalam membina kemampuan bawahan baik dalam pembinaan moral maupun prestasi dalam mengerjakan tugasnya. Sebagai Manager, kepala sekolah SMPK Angelus Custos II Surabaya bertanggungjawab dalam proses merencanakan, mengorganisasikan, melaksanakan, memimpin dan mengendalikan usaha para bawahan serta mendayagunakan seluruh sumber daya dalam rangka mencapai visi dan misi sekolah, dengan komunikasi yang dibangun kepala sekolah pada bawahanya yang membuat bawahanya sering terbuka dan saling memberikan pendapat sehingga adanya ineraktif banyak pihak yang semakin menguatkan suatu perencanaan dan terkadang kepala sekolah melibatkan dirinya dalam kegiatan sebagai bentuk support lainya terhadap bawahan. Sebagai administrator kepala sekolah kerap kali memeriksa pendokumenan agar selalu terstruktur sehingga saat adanya pemeriksaan dinas ataupun kebutuhan untuk kegiatan lain dapat dengan mudah ditemukan. Sebagai supervisor kepala sekolah memerankan kepemimpinanya dalam meningkatkan kinerja bawahan dengan melakukan pengawasan dan pengendalian untuk meningkatkan kinerja tenaga kependidikan lewat breafing wajib dipagi hari atau evaluasi yang dilakukan setiap selesainya kegiatan dan akhir semester. Sebagai leader kepala sekolah kepala sekolah selalu membuka komunikasi dua arah untuk memberikan petunjuk dan melakukan pengawasan terhadap bawahan. Sebagai inovator kepala sekolah SMPK Angelus Custos II kerap kali memiliki strategi dalam meningkatkan budaya dan mutu sekolah dengan gagasan-gagasan baru untuk lingkungan sekolah sampai pada mengembangkan model pembelajaran inovatif. Sebagai Motivator kepala sekolah sering memotivasi bawahanya agar dengan semangat meningkatkan kinerja dimulai pengaturan suasana kerja, dorongan, penghargaan secara efektif sampai pada penyediaan berbagai pusat pengembangan media belajar terutama saat pembelajaran daring sekarang ini sebagai contohnya adalah e-learning.

\section{Budaya Sekolah}

Dalam peran kepemimpinanya untuk meningkatkan budaya sekolah, Kepala sekolah SMPK Angelus Custos II Surabaya mengiplementasikan budaya sekolah dengan penguatan Pendidikan karakter. Seperti pendapat Deal dan Peterson dalam Supardi (2015) yang mengatakan bahwa budaya sekolah adalah sekumpulan nilai yang melandasi perilaku, tradisi, kebiasaan, keseharian, dan symbol-simbol yang dipraktekan masyarakat sekolah. Pembiasaan ini diintegrasikan dalam keseluruhan kegiatan disekolah yang tercermin dari suasana dan lingkungan sekolah yang kondusif (Kemdikbud, 2017). Dalam hal ini identifikasi dan deskripsi pengembangan budaya sekolah melalui Pendidikan karakter yang diterapkan dalam sekolah.

Dari penelitian yang dilakukan di SMPK Angelus Custos II Surabaya, menunjukan hasil dimana masyarakat sekolah bertindak sesuai dengan norma-norma yang ada dalam 5 nilai Pendidikan karakter yaitu; Religius, Nasionalis, Mandiri, Gotong Royong, dan integritas. Merujuk pada Kemdikbud (2017) penguatan pendidikan karakter (PPK) berbasis budaya sekolah juga dapat dilakukan dengan menginternalisasikan nilai-nilai karakter melalui kegiatan rutin, kegiatan spontan dan keteladanan. Dalam konsep dan pedomaan penguatan Pendidikan karakter kementrian Pendidikan dan kebudayaan yang diintegrasikan SMPK Angelus Custos II berdasarkan nilai-nilai ini dijelaskan sebagai berikut; 
a) Religius

Nilai karakter religius mencerminkan keberimanan terhadap Tuhan yang Maha Esa yang diwujudkan dalam Tindakan dalam melaksakanakn ajaran agama dan kepercayaan yang dianut, mengharagai perbedaan agama, menjunjung tinggi sikap toleransi dalam pelaksanaan ibadah, menjujung tinggi kerukunan dengan penganut agama lainya. Nilai karakter religious meliputi tiga dimensi relasi sekaligus yaitu hubungan individu dengan Tuhan, Individu dengan sesama, dan individu dengan alam semesta yaitu menjaga keutuhan ciptaan.

Kepala sekolah SMPK Angelus Custos II Menegakan nilai karakter religius dengan Menyusun tatakrama dan tata tertib kehidupan akademik dan sosial sekolah sesuai dengan nilai-nilai yang diajarkan dalam karakter religius, yang mendukung terwujudnya peningkatan budaya sekolah yang baik. kemudian tatakrama dan tata tertib itu diimpelementasikan dalam kehidupan akademik dan social sekolah secara tepat dengan mengorganisasikan semua potensi sumber daya yang ada untuk membudayakan nilai-nilai religius yang ada. Berdasarkan temuan penelitian Rozafi (2019) pelaksanaan Pendidikan karakter berbasis budaya sekolah pada dasarnya tercermin dari kegiatan pembiasaan yang didalamnya dimasukan nilainilai utama Pendidikan Karakter.

b) Nasionalis

Nilai karakter nasionalis merupakan cara berpikir, bersikap, dan berbuat yang menunjukan kesetiaan, kepedulian, dan penghargaan yang tinggi terhadap Bahasa, lingkungan fisik, sosial, budaya, ekonomi, dan politik bangsa, menempatakan kepentingan bangsa dan negara di atas kepentingan kelompoknya, dalam impelemntasinya ini, peserta didik menjadwalkan kegiatan-kegiatan yang mencerminkan nilai nasionalis, seperti menyanyikan lagu Indonesia raya sebelum kelas setiap hari senin jika tidak ada upacara apel bendera, berbaris sebelum masuk kelas, dan kegiatan terjadwal lainya yang mampu meningkatkan rasa nasionalis dalam diri peserta didik.

c) Mandiri
Nilai karakter mandiri merupakan sikap dan perilaku tidak bergantung pada orang lain dan mempergunakan segala tenaga, pikiran, waktu, untuk merealisasikan harapan, mimpi, dan cita-cita. Dalam pengimpelemntasianya peserta didik diminta untuk membuatkan jadwal kegiatan harian besok harinya, selain sebagai pengingat, peserta didik juga diajarkan agar mandiri dalam menyiapkan jadwal yang akan dijalankan.

d) Gotong Royong

Nilai karakter gotong royong mencerminkan Tindakan menghargai semangat kerja sama dan bahu membahu menyelesaikan persoalan Bersama, menjalin komunikasi dan persahabatan, memberi bantuan atau pertolongan pada orang-orang yang membutuhkan. Dalam nilai gotong royong ini, SMPK Angelus Custos II Surabaya melaksanakan beberapa kegiatan yang mencerminkan nilai gotong royong sebagai kegiatan pembiasaan agar nilai gotong royong bisa tertanam dalam diri peserta didik. Sebagai contoh kegiatan yang dilaksanakan salah satunya adalah memberihkan lingkungan sekolah dan kegiatan rutin lainya seperti aksi solidaritas berupa pengumpulan dana untuk membantu warga sekolah yang membutuhkan sehingga jika ada salah satu masyarakat sekolah yang mengalami kesusahan seperti sedang berduka, maka uang yang dikumpulkan akan disumbangkan untuk hal tersebut. Kemudian bakti social diluar.

e) Integritas

Nilai karakter integritas merupakan nilai yang mendasari perilaku yang didasarkan pada upaya menjadikan dirinya sebagai orang yang selalu dipercaya dalam perkataan, Tindakan, dan pekerjaan, memiliki komitmen dan kesetiaan pada nilai-nilai kemanusiaan dan moral (integritas moral). Pengimplementasian nilai intergritas yang diterapkan SMPK Angelus Custos II Surabaya itu salah satunya penyediaan kotak kejujuran, yang menjadikan peserta didik berlatih untuk jujur mengakui kesalahan dan menyadari bahwa perbuatan yang dialakukanya itu adalah kesalahan. Jadi dengan nilai integritas ini peserta didik akan lebih jujur bertutur kata dan dalam bertindak. Perilaku $5 \mathrm{~S}$ juga 
Nampak di SMPK Angekus Custos II Surabaya, hal ini dilihat dari saat peserta didik berpapasan dengan guru maka akan saling melakukan salam dan berjabat tangan, ataupun saat pulang sekolah peserta didik akan menjabati guru yang mengajar dijam terakhir yang sudah berdiri dipintu sebelum peserta didik keluar satu persatu.

a. Prinsip Pengembangan Budaya Sekolah

Dalam mengembangakan budaya sekolah, kepala sekolah SMPK Angelus custos II Surabaya mengupayakan pengacuan pada beberapa prinsip dalam kepemimpinanya sebagaimana kepala sekolah mengiplementasikan pemimpin yang visioner yaitu berfokus pada visi, misi dan tujuan sekolah, dimana pengembangan budaya sekolah harus senantiasa sejalan dengan visi, misi dan tujuan sekolah. Fungsi visi, misi dan tujuan sekolah adalah mengarahkan pengembangan budaya sekolah. Visi tentang keunggulan mutu misalnya, harus disertai dengan programprogram yang nyata mengenai penciptaan budaya sekolah. Kepala sekolah juga membangun budaya komunikasi formal dan nonformal yang disampaikan secara efektif dan efisien.

Kepala sekolah SMPK Angelus Custos II Surabaya juga sangat inovatif, dengan dimensi budaya organisasi, kepala sekolah semakin berani dalam mengambil resiko untuk meningkatkan budaya sekolah dengan segala inovasi-inovasi yang dirancang. Strategi program yang jelas itu, dilakukan oleh kepala sekolah membantu menopang budaya sekolah secara operasional dan pengembangan budaya sekolah yang diarahkan pada sasaran yang sedapat mungkin dapat diukur, seperti dalam pencapaiannya sasaran kegiatan belajar mengajar yang mempunyai tujuan, dimana tujuan itu bertahap dan berjenjang mulai dari sangat operasional dan konkret. Presepsi guru dan peserta didik itu kemudian akan mengenai sasaran yang akan diwujudkan kedalam ciri-ciri perliku kepribadian atau Pendidikan karakter yang ditekankan dalam budaya sekolah. Dengan begitu dapat mempermudah pengukuran capaian kinerja SMPK Angelus Custos II Surabaya.

Untuk mengetahui kinerja pengembangan budaya sekolah jangka Panjang, kepala sekolah SMPK Angelus Custos II juga melakukan evaluasi secara rutin seperti breafing wajib di pagi hari dan supervise guru. Kepala sekolah tidak hanya akan memberikan instruksi dalam breafing tetapi kepala sekolah juga melakukan evaluasi terhadap kegiatan-kegiatan yang mungkin sudah dilakukan sebelumnya jika masih belum menemukan titik terang dalam penyelesaianya. Sedangkan evaluasi bertahap jangka Panjang juga sering dilakukan seperti evaluasi besar di akhir semester dimana kepala sekolah dan guruguru akan menilai hasil kinerja selama satu semester dalam menyelesaikan programprogram kerja yang diberi kepada masingmasing bidang maupun tugas-tugasnya sendiri sebagai seorang pendidik, tenaga pendidik dan karyawan. Karena itu kepala sekolah mengembangkan sistem evaluasi terutama dalam hal kapan evaluasi itu dilaksanakan, siapa yang melakukan dan bagaimana mekanisme tindak lanjut yang harus dilakukan. Keputusan Bersama yang dilakukan saat dilaksanakanya evaluasi menjadi ciri budaya organisasi yang positif dan mampu meningkatkan komitmen masyarakat sekolah dalam melaksanakan keputusan-keputusan tersebut.

b. Asas Pengembangan Budaya Sekolah

Selain mengacu pada prinsip dalam upaya meningkatkan budaya sekolah, kepala sekolah juga seyogyanya mengacu pada asas-asas seperti kerja sama team (team work) yang menjadi nilai keharusan dan menjadi aktivitas yang bertujuan untuk membangun kekuatan-kekuatan atau sumber daya yang dimiliki oleh personil sekolah. Kemampuan dalam mengerjakan tugas dan tanggungjawab bersama dalam lingkungan pembelajaran tidak hanya ditunjukan dalam bidang akademik tetapi juga dalam bersikap dan bertindak yang mencerminkan pribadi pendidik.

Kemudian kedisiplinan yang ditekankan dalam sekolah membentuk ketaatan pada 
peraturan dan sanksi yang berlaku dalam lingkungan sekolah SMPK Angelus Custos II, disiplin yang dimaksudkan dalam asas ini adalah sikap dan perilaku disiplin yang muncul karena kesadaran dan kerelaan untuk hidup teratur dan rapi yang kemudian dijadikan atribut sekolah yang tidak berlaku pada orang tertentu saja tetapi untuk semua masyarakat sekolah.

Kepala sekolah juga menekankan semangat kerja itu untuk memberikan kepuasan terhadap peserta didik dan masyarakat, usaha ini untuk memperbaiki dan meningkatkan kemampuan dan kompetensi diri dalam melaksanakan tugas dan tanggungjawab sebagai budaya yang muncul dalam pribadi baik kepala sekolah, guru, dan tenaga pendidik lainya dalam memberikan pelayanan sekolah dengan baik dengan harapan akan menumbuhkan iklim yang ramah, menumbuhkan rasa puas dan nyaman. Seperti yang dilakukan oleh kepala sekolah dengan dibuatnya wilayah-wilayah yang dapat membuat suasana dan memberi nuansa yang indah, asri dan menyenangkan, contohnya taman sekolah yang ditata dengan baik, Kawasan bebas masalah serta penerapan budaya Pendidikan karakter $5 \mathrm{~S}$ yaitu; senyum, salam, sapa, sopan, santun.

Nilai kejujuran dan rasa hormat dalam menciptakan budaya sekolah yang baik juga ditekankan oleh kepala sekolah, sehingga tidak adanya perbedaan posisi atau keududukan disekolah dimulai dari guruguru sampai pada satpam karena kepala sekolah berpikir mereka adalah satu kesatuan yang memiliki tujuan yang sama yaitu tercapainya tujuan, visi misi sekolah. Rasa hormat ini memperlihatkan sikap peduli dapat diungkapkan dengan cara $5 \mathrm{~S}$ kepada siapa saja yang ditemui dengan begitu menjadikan sekolah dapat dipercaya karena adanya perasaan dihargai dan dibutuhkan.

\section{Mutu sekolah}

Mutu sekolah SMPK Angelus Custos II Surabaya diarahkan kepada komponenkomponen penentu mutu proses belajar mengajar di sekolah, yaitu: a. Peningkatan Profesionalisme dan kualitas Guru

SMPK Angelus Custos II menjalankan kegiatan KKG atau kelompok kerja guru sekota surabaya. dalam kegiatan ini, guru mata pelajaran Bahasa, Matematika, IPA dan IPS tingkat SMP melakukan sebuah pelatihan di awal tahun pembelajaran untuk melakukan penyusunan RPP Bersama-sama dan diwaktu berikutnya melatih sekaligus Menyusun kisikisi soal untuk UTS dan UAS dan Bersamasama belajar untuk membuat media pembelajaran. Kegiatan yang dilakukan ini membantu meningkatkan materi yang dapat menambah pengetahuan. Kemudian adanya peningkatan dalam pemakaian metode sebagai salah satu indicator dalam peningkatan kualitas Pendidikan, dalam kegiatan ini guruguru juga belajar bagaimana metode yang diterapkan dalam penggunaanya sesuai dengan materi yang disajikan sehingga peserta didik tidak merasa jenuh atau monoton.

b. Kemudian peningkatan sarana dan prasarana Dalam peningkatan sarana, metode dan Teknik yang dipergunakan dalam rangka meningkatakan efektivitas komunikasi dan interaksi edukatif antara pendidik dan peserta didik dalam proses kegiatan belajar mengajar, SMPK Angelus Custos II juga fokus dalam peningkatan sarana yang meliputi Gedung sekolah, fasilitas ruangan seperti meja, kursi, alat peraga, media pembelajaran yang digunakan dan lainya. Dan prasarana merupakan semua komponen yang secara tidak langsung menunjang jalanya proses belajar mengajar atau pendidikan di sekolah sebagai contoh: Tata tertib, suasana dan tatanan lingkungan sekolah. Lingkungan fisik sekolah cukup besar peranannya dalam menciptakan kondisi dan suasana belajar yang menyenenangkan bagi peserta didik. Lingkungan ini akan mengakibatkan peserta didik menjadi tertantang untuk terus belajar sehingga pada akhirnya membawa kepada prestasi belajar.

c. Peningkatan kualitas belajar

Kepala sekolah SMPK Angelus Custos II menekankan penggunaan metode pembelajaran yang sesuai guna merangsang minat untuk belajar. seperti yang dilakukan 
saat pandemic ini, kepala sekolah menggunakan e-learning sebagai media penghubung guru dan peserta didik dalam proses pembelajaran. Media ini tidak hanya menyajikan memfasilitasi virtual meet tetapi juga terhubung dengan penyimpanan materi dan tugas-tugas peserta didik lengkap dengan jadwalnya. Selanjutnya setelah peserta didik terangsang terhadap pendidikan maka pendidik tinggal memberikan motivasi secara kontinew. sehingga peserta didik dapat menerima pengalaman yang dapat menyenangkan hati para peserta didik sehingga menjadikan peserta didik semangat belajar.

d. Pembinaan Manajemen Pendidikan

Dalam kaitan dengan manajemen sekolah, kepala sekolah memperhatikan bawahan agar perlu memahami dengan baik berbagai hal, seperti aspek-aspek manajemen sekolah, tahap-tahap manajemen sekolah, penataan dan pengorganisasian sekolah. Untuk mewujudkan disiplin dalam lingkungan sekolah kepala sekolah melakukan pendekatan dan teknik yang tepat sesuai situasi dan kondisi sekolah seperti adanya komunikasi yang baik dan terkadang disampaiakan secara nonformal agar tidak terkesan menegangkan sehingga bawahan akan menaggapi dengan santai dan semakin berani dalam menyampaikan pendapat.

e. Peningkatan Partisipasi ke Masyarakat

SMPK Angelus Custos II mengadakan kegiatan dimana masyarakat sekolah mencari kesempatan agar dapat memberikan kontribusinya terhadap masyarakat, baik melalui sumbangan atau melakukan kunjungan sehingga nilai tersebut memberikan feedback terhadap peningkatan mutu pendidikan dengan melihat bahwa sekolah memiliki peran dalam kepedulian sosial.

\section{KESIMPULAN}

Berdasarkan hasil penelitian dan pembahasan yang di lakukan peneliti terhadap "kepemimpinan kepala sekolah dalam meningkatkan budaya dan mutu SMPK Angelus Custos II Surabaya" dapat disimpulkan sebagai berikut:
1. Dengan adanya peran kepemimpinan kepala sekolah dalam mendukung budaya dan mutu di SMPK Angelus Custos II Surabaya, semakin banyak kegiatan yang lebih diperhatikan dan dijalankan dengan baik sehingga dinilai sebagai elemen penting dalam menentukan arahnya keberhasilan sekolah. Peranan kepemimpinan kepala sekolah dalam mendukung budaya dan mutu sekolah dimana kepala sekolah harus memahamai kultur sekolah dan menyadari bahwa hal itu tidak lepas dari peran kepemimpinannya. Sehingga kepala sekolah yang cukup perhatian dan komitmen dalam peran kepemimpinan dan peduli terhadap bawahannya, maka akan bisa menguatkan kultur sekolah yang baik. Terwujudnya visi, misi, dan tujuan sekolah ini perlu didukung dengan program-program sekolah yang tegas dan rinci yang mengarah pada terwujudnya budaya dan mutu sekolah yang baik.

2. Budaya dan Mutu SMPK Angelus Custos II Surabaya sudah cukup maksimal. Dengan terstrukturnya program penerapan nilai-nilai budaya sekolah, fasilitas sarana dan prasarana sekolah yang cukup lengkap, seperti ruangan laboratorium, ruangan ektrakulikuler sampai dengan kebutuhan warga sekolah yang cukup terpenuhi.

\section{SARAN}

Berdasarkan hasil penelitian, peneliti

merekomendasikan hal-hal sebagai berikut:

1. Bagi kepala sekolah, guru, tenaga kependidikan dan stakeholder lainya, hendaknya dapat mengimpelemntasikan nilai-nilai budaya yang tertuang dalam tulisan ini dalam mendukung budaya dan mutu sekolah yang baik.

2. Kepala sekolah dan guru-guru meningkatkan kemampuan dalam menggunakan media pembelajaran berbasis IT dengan megnikuti bimtek ataupun workshop yang dapat membantu meningkatkan skill dalam membuat media pembelajaran berbasis teknologi.

3. Hasil penelitian ini dapat dijadikan sebagai referensi dan bahan evaluasi bagi kepala sekolah guna menyiapkan strategi kepemimpinan yang sesuai dalam 
meningkatkan budaya dan mutu sekolah. Temuan terkait penerapan nilai Pendidikan karakter dalam budaya dan mutu sekolah dapat dijadikan acuan lain dalam mengipresentasikan strategi sekolah. Temuan tersebut memberikan informasi bagaimana kepala sekolah berperan sebagai seorang pemimpin dalam mendukung budaya dan mutu sekolah.

\section{DAFTAR PUSTAKA}

Adnan, M. (2016). The Effect Of Madrasah Headmaster Leadership And Organisation Circumsatances On The Teachers Performance In Pondok Pesantren Qamarul Huda Bagu Priggarata Central Lombok. Jmm Unram-Unram Management Review, 5(2).

Agustina, Agustina, Sulton Djasmi, and Irawan Suntoro. "Pengaruh Kepemimpinan Kepala Sekolah Iklim Kinerja Guru Terhadap Mutu Pendidikan Lampung Tengah." Jurnal Manajemen Mutu Pendidikan 4.1 (2016).

Ahmad Susanto, M. P. (2016). Teori belajar dan pembelajaran di sekolah dasar. Kencana.

Arikunto, Suharsimi. 2002. Prosedur Penelitian, Suatu Pendekatan Praktek. Jakarta: Rineka Cipta.

Ariyani, R. (2017). Kepemimpinan kepala sekolah dalam pengembangan profesionalisme guru. Jurnal AlAfkar, 5(1).

Baharuddin, B., Elihami, E., Arifin, I., \& Wiyono, B. B. (2017). Kepemimpinan Moral Spiritual Kepala Paud Dalam Meningkatkan Pembelajaran Karakter Anak Usia Dini. Jurnal Pendidikan Islam, 8(2), 103-122.

Bass, B. M., Waldman, D. A., Avolio, B. J., \& Bebb, M. (1987). Transformational leadership and the falling dominoes effect. Group \& Organization Studies, 12(1), 73-87.

Basuki, Sulistyo. 2006. Metode Penelitian. Jakarta: Wedatama Widya Sastra.

Bush, T. (2007). Educational leadership and management: Theory, policy and practice. South African journal of education, 27(3), 391-406.

Bush, T. 2008. Leadership and Management Development inEducation.London: Sage.

Damero, R., \& Andri, S. (2017). Pengaruh Fungsi Kepemimpinan Terhadap Prestasi Kerja Karyawan (Kasus PT. Arara Abadi Distrik Resort Rasau Kuning Perawang)(Doctoral dissertation, Riau University).

Departemen Pendidikan dan Kebudayaan, 1991.Kamus Besar Bahasa Indonesia, Jakarta: PT. Balai Pustaka

Depdiknas, (2003). Undang-undang Nomor 20 tahun 2003 tentang SistemPendidikan Nasional. Jakarta: Depdiknas RI

Diyati, Haryani, and Muhyadi Muhyadi. "Peran Kepemimpinan Kepala Sekolah Dalam Pengembangan Budaya Sekolah Di Sdn Kwayuhan, Kecamatan Minggir, Sleman." Jurnal Akuntabilitas Manajemen Pendidikan 2.1 (2014): 2843.

Emzir. 2010. Meteodoligi Penelitian Pendidikan:

Kuantitatif dan Kualitatif. Jakarta: Rajawali Pers

Fadhli, M. (2013). Hubungan Kepemimpinan Kepala Sekolah Dan Budaya Sekolah Dengan Keefektifan Sekolah Di Smp Kota Medan (Doctoral Dissertation, Unimed).

Hadari Nawawi. 2005. Penelitian Terapan. Yogyakarta: Gajah Mada University Press

Hasibuan, Malayu Sp. 2012. Manajemen SDM. Edisi Revisi, Cetakan Ke Tigabelas. Jakarta: Bumi Aksara

Hernita, Rika. "Kepemimpinan Kepala Sekolah Dalam Mengembangkan Budaya Sekolah Melalui Manajemen Berbasis Sekolah." JMKSP (Jurnal Manajemen, Kepemimpinan, dan Supervisi Pendidikan) 3.2 (2018): 261-269.

Hersey, P and Blanchard, K.H (1993). Management of Organizational behaviour: utilizing human resources (6th).Englewood Cliffs, New Jersey: Prentice Hall. 
https://setkab.go.id/wp

content/uploads/2017/09/Perpres_Nom or_87_Tahun_2017.pdf

Idris, M. Kepemimpinan Kepala Madrasah dalam Meningkatkan Mutu Pendidikan di MIN 3 Waykanan. Diss. UIN Raden Intan Lampung, 2019.

Indahwati, Y. D. (2018). Strategi Kepala Sekolah dalam pengembangan kompetensi profesional guru untuk meningkatkan mutu pendidikan di MA Hidayatul Mubtadiin Tasikmadu Lowokwaru Malang (Doctoral dissertation, Universitas Islam Negeri Maulana Malik Ibrahim).

Ismayani, A. I., Niswaty, R., \& Darwis, M. (2015). Eranan Kepala Sekolah Sebagai Leader Di SMA Negeri 8 Kabupaten Bulukumba. Jurnal Ad'ministrare, 2(2), 101-107.

Kosim, M. (2017). Pengaruh Kepemimpinan Kepala Sekolah terhadap Kinerja Guru untuk Mewujudkan Mutu Pembelajaran. Khazanah

Akademia, 1(01), 30-38.

Laili, R. (2015). Kepemimpinan Kepala Sekolah dalam mengembangkan mutu sumberdaya guru di SMA Negeri 1 Tumpang (Doctoral dissertation, Universitas Islam Negeri Maulana Malik Ibrahim).

Lestari, Lesti. Peranan Kepemimpinan Kepala Sekolah Dalam Meningkatkan Mutu Pendidikan (Studi Kualitatif di Mts Masyariqul Anwar Labuan Caringin). Diss. Uin Smh Banten, 2019.

Lizana, A., \& Afriansyah, H. (2020). Kepemimpinan pendidikan.

Louis, K. S., Leithwood, K., Wahlstrom, K. L., Anderson, S. E., Michlin, M., \& Mascall, B. (2010). Learning from leadership: Investigating the links to improved student learning (Vol. 42). New York, NY: Wallace Foundation.

Manora, Hecksa. "Peranan Kepala Sekolah Dalam Meningkatkan Mutu Pendidikan." Edification Journal: Pendidikan Agama Islam 1.1 (2019): 119-125.
Miles, M. B. \& Huberman, M. (1992). Analisis Data Kualitatif. Jakarta: Penerbit Universitas Indonesia

Miles, Matthew B. \& A. Michael Huberman. 2009. Analisis Data Kualittaif. Jakarta: UI-Press

Moleong Lexy J. 2004, Metodologi Penelitian Kualitatif, Bandung: Remaja Rosdakarya.

Moleong, L.J. (2011). Metodologi Penelitian Kualitatif Edisi Revisi. Bandung: PT. Remaja Rosdakarya.

Moleong, Lexy. 2001. Meteodologi Penelitian Kualitatif. Bandung: Remaja Rosdakarya

Mulyasa, E. 2009. Menjadi Kepala Sekolah Dalam Konteks Menyukseskan MBS dan KBK. Bandung: PT Remaja Rosdakarya

Mulyasa. 2005. Manajemen Berbasis Sekolah. Jakarta: Depdiknas.

Nurhaya, Nurhaya, Aunurahman Aunurahman, and Usman Radiana. "Kepemimpinan Kepala Sekolah Dalam Meningkatkan Mutu Pendidikan Di Sdn 4 Sungai Nilam Jawai." Jurnal Pendidikan dan Pembelajaran Khatulistiwa 6.11.

Nurvita, Almi, Falita Alam, and Iqbal Abdullah. "Kepemimpinan Kepala Sekolah Perempuan Dalam Meningkatkan Budaya Sekolah." Jurnal Administrasi Pendidikan 27.1 (2020): 42-52.

Nuryani, N. (2014). Kepemimpinan Kepala Sekolah Dalam Meningkatkan Mutu Pendidikan (Studi Situs SMP Negeri 3 Ungaran) (Doctoral dissertation, Universitas Muhammadiyah Surakarta). Paine, Lynn. 1994. Managing for Organizational Integrity. Harvard Business review.

Pidarta, Made. 2000. Landasan Pendidikan. Jakarta: Rineka Cipta.

Pidarta, Made. 2009. Supervisi Pendidikan Kontekstual. Jakarta: Rineka Cipta

Putra, J. A. (2020). Peran Kepala Sekolah Sebagai Inovator di Sekolah Menengah Pertama Negeri Kota Pariaman. Jurnal Bahana Manajemen Pendidikan, 2(1), 347-355.

Rahmat, N., Sepriadi, S., \& Daliana, R. (2017). Pembentukan Karakter Disiplin Siswa 
Melalui Guru Kelas Di Sd Negeri 3 Rejosari Kabupaten Oku Timur. JMKSP (Jurnal Manajemen, Kepemimpinan, dan Supervisi Pendidikan), 2(2).

Ridho, M. A. (2019). Kepemimpinan Kepala Sekolah Dalam Mengembangkan Budaya Sekolah Efektif di Sekolah Dasar. Jurnal Dinamika Manajemen Pendidikan, 3(2), 114-129.

Rinda, Arum. Strategi Kepala Madrasah dalam Pengembangan Budaya Mutu Pendidikan: Studi Kasus di Madrasah Tsanawiyah Negeri 2 Malang. Diss. Universitas Islam Negeri Maulana Malik Ibrahim, 2018.

Rivai, A. (2007). Kepemimpinan Dalam Masyarakat Modern. Jakarta: $P T$. Rineka Cipta.

Robbins, Stephen dan Coulter, Mary, 2002, Manajemen, Jakarta: Gramedia

Rusdiana, E. (2018). Peran Kepemimpinan Kepala Sekolah Sebagai Educator dalam Meningkatkan Kompetensi Guru. Indonesian Journal of Education Management \& Administration Review, 2(1), 231-236.

Said, A. (2018). Kepemimpinan kepala sekolah dalam melestarikan budaya mutu sekolah. EVALUASI: Jurnal Manajemen Pendidikan Islam, 2(1), 257-273.

Saimima, M. Sahrawi. "Kepemimpinan Kepala Sekolah Berbasis Budaya Etis Dalam Meningkatkan Mutu Sekolah (Studi Kasus Di MA Bilingual Batu)." alIltizam: Jurnal Pendidikan Agama Islam 2.2 (2017): 234-248.

Sanjani, M. A. (2018). Kepemimpinan Demokratis Kepala Sekolah. Jurnal Serunai Administrasi Pendidikan, 7(1).

Schein, Edgar. H. 2004. Organizational Culture and Leadership. $3^{\text {rd }}$ Edition. San Fransisco : John Wiley \& Sons, inc.,

Smith, S.C. \& Piele, P.K. (2006). School leadership. Handbook for excellence in student learning. California: Corwin Press.

Soedarmo, U. R., \& Herman, M. (2018). Kemampuan Manajerial Kepala
Sekolah dalam Meningkatkan Prestasi Sekolah: Studi di SMP Negeri 1 Cihaurbeuti Kabupaten Ciamis. Indonesian Journal of Education Management \& Administration Review, 1(2), 99-106.

Sugiyono. 2006. Metode Penelitian Kuantitatif Kualitatif dan R\&D. Bandung: Alfabeta.

Sugiyono. 2009. Statistik untuk Penelitian. Bandung: Alfabeta

Sugiyono. 2011. Metode Penelitian Administratif. Bandung: Alfabeta.

Sugiyono. 2013. Metode Penelitian Pendidikan Pendekatan Kuantitatif, Kualitatif, dan R\&D. Bandung: Alfabeta.

Sugiyono. 2015. Metode Peneltian Pendidikan. Cet. Ke-11. Bandung: Alfabeta.

Sukardi. 2010. Metodologi Penelitian Pendidikan. Jakarta: PT. Bumi Aksara.

Supriyadi, U. D. (2009). Pengaruh Desentralisasi Pendidikan Dasar Terhadap Kualitas Pendidikan Di Kabupaten Jembrana Provinsi Bali. Jurnal Kependidikan: Penelitian Inovasi Pembelajaran, 39(1).

Syaeba, M. (2018). Pengaruh Kepemimpinan Kepala Sekolah, Motivasi Kerja Guru Dan Budaya Sekolah Terhadap Kedisiplinan Siswa Di Kabupaten Polewali Mandar. Pepatudzu: Media Pendidikan dan Sosial Kemasyarakatan, 13(1), 43-56.

Syafaruddin.(2002).Manajemen Mutu Terpadu dalam Pendidikan. Jakarta. Grasindo

Thomas, P. (2013). Faktor Determinan Produktivitas Sekolah. Jurnal Penelitian dan Evaluasi Pendidikan, 17(1), 55-71.

Tresnani, L., Sumadi, S., \& Karwan, D. H. (2017). Pengaruh Budaya Kerja, Sarana Dan Prasarana Pengalaman Kerja Terhadap Kompetensi Profesional Guru. Jurnal Manajemen Mutu Pendidikan, 5(2).

Usman, H (2015). Proyek penulisan buku ajar Univeristas Negeri Jogyakarta.

Utomo, S. (2020). Pengaruh Gaya Kepemimpinan Transformasional dan Budaya Organisasi terhadap Kinerja 
Karyawan. Jurnal Administrasi Bisnis (Jab), 10(1), 48-54.

Wahyudi, P. Pengaruh Gaya Kepemimpinan Situasional Dan Budaya Organisasi Terhadap Kinerja Pegawai (Studi Pada Pegawai Sekolah Dasar Negeri Di Kelurahan Sungai Beliung Pontianak). Jurnal Manajemen Update, 9(3).

Widiarta, E., Perizade, B., \& Zunaidah, Z. (2015). Pengaruh Budaya Perusahaan Dan Kepemimpinan Transformasional Terhadap Kinerja Karyawan Pertamina Ru Iii Plaju Pada Awal Transformasi Pertamina. Jurnal Manajemen Dan Bisnis Sriwijaya, 13(2), 137-154. 